\title{
ENHANCED COOPERATION \\ IN FEDERAL STATES: DEMOCRACY THROUGH ASYMMETRY
}

\author{
Gulnara R. Shaikhutdinova \\ Doctor of Legal Science, Master of Laws (LL.M), Professor, \\ Department of International and European Law. \\ Kazan (Volga Region) Federal University. \\ Address: 18 Kremlevskaya St., 420008, Kazan, Russian Federation. \\ E-mail: ildar_sh@mail.ru
}

\begin{abstract}
The article focuses on a comparative analysis of the cooperation mechanisms of a federal center and constituent units based on the constitutional principle of flexibility. Cooperation mechanisms in Switzerland, Canada, the USA and the Russian Federation are studied in detail with the purpose of identifying enhanced cooperation forms and revealing the principle of flexibility influence on these forms. It is determined that enhanced cooperation, based on the treaties between a federal center and constituent units, inevitably leads to asymmetry within the federal system. The hypothesis of the article is that implementation of the principle of flexibility in the form of enhanced cooperation between a federal center and constituent units ensure democratic change and effectiveness of federations. Asymmetric federation as a pluralistic form ensures democratic rights, minorities' rights, representation and participation. It represents a tool for achieving "unity in diversity".
\end{abstract}

Keywords: federalism; asymmetry; enhanced cooperation; principle of flexibility; democracy.

Citation: Shaikhutdinova, G.R. (2017). Enhanced Cooperation in Federal States: Democracy through Asymmetry. Public Administration Issues, Special Issue (electronic edition), pp. 72-82 (in English); doi: 10.17323/1999-5431-2017-0-5-72-82.

\section{Introduction}

There are some federal states in existence which recognize the principle of flexibility being understood as the possibility for a number of constituent units of federations to cooperate in certain fields based on agreements among them or in other forms, sometimes with the participation of a federal center. In our previous articles, we referred to it as enhanced cooperation within federal settings (Shaikhutdinova, 2016, p. 138). 
In the present article, we shall explore how the principle of flexibility being a constitutional principle in a number of modern federations is implemented and assess its consequences for the theory and practices of federalism (Goudappel, Conlan, Van Wissen, 2002). There exist federal states, which recognize the principle of flexibility being understood as a possibility for a number of constituent units of federations to cooperate in certain fields based on agreements among them or in other forms, sometimes with participation of a federal center. They are referred to as an enhanced cooperation within federal settings.

The main goal is to study how the asymmetry as a result of enhanced cooperation within federal settings leads to democratic change and promotes the effectiveness of federations.

The thesis that federalism fosters democracy has already been proven by many researchers (Elazar, 1987; Fleiner, 2005; Farukshin, 2003; Diamond, 1961). Federalism has a strong predisposition for democracy (Elazar, 1995, p. 13). Our assumption is that asymmetric federalism, which gives rise to the particular group interests, rights and liberties, including national minorities', enhances those sides of democracy, which symmetric federalism, due to its equality attitude, is incapable of achieving.

\section{Case studies}

For our case studies in this research, we take examples from Switzerland, Canada, the USA and the Russian Federation.

Switzerland. The existing Swiss federal system is unconceivable without intergovernmental cooperation in its various forms, including institutions and agreements among the constituent units, sometimes with the participation of the federal center. Article 48 of the Swiss Constitution states that the cantons may enter into agreements with each other and establish common organizations and institutions. The Confederation may participate in such organizations or institutions within the scope of its powers (the Constitution of Switzerland, 1999).

Strong intergovernmental cooperation is the consequence of the centripetal character of the Swiss federation and its origin from the former independent sovereign entities, now cantons. The intergovernmental institutions and relations are closely linked to, or even derive from, one of the distinctive features of Swiss federalism, namely the close co-operation existing between the sub-national entities (the cantons) and also between the cantons and the centre (the Confederation) (López - Basaguren \& Escajedo San Epifanio, 2013, p. 49).

Enhanced cooperation in Switzerland in the last two decades was extremely active and is represented by intergovernmental conferences, institutions and agreements. The other forms are round tables, working parties, task forces, consultation procedures for cantons to participate in the federal decision-making process, parliamentary committee hearings, and cantonal representatives in federal administration, the House of the cantons.

There are more than 800 intergovernmental agreements within Switzerland, some of them with the participation of the Confederation, dealing with a large variety of subject matters: administrative and of legal character, contain- 
ing legal norms that are binding for the cantons having ratified the agreements (ibid., 2013, p. 57). Recent examples are the Cooperation Agreement between the Confederation and Cantons (2015), the agreement on measures against hooliganism, the agreement regulating the activities of private security enterprises, and the agreement on the harmonization of cantonal legislations in the field of school education.

All the above forms of enhanced cooperation within the Swiss federal system prove the thesis that both horizontal and vertical cooperation is in place in Switzerland. The intense and growing character of different forms of interaction among cantons and of the latter with the federal center is strong evidence of the authority cantons possess after the century-long process of transferring powers to the Confederation. The dialectics of the Swiss federal system demonstrate how the evolutionary development has spiralled, beginning with independent and strong cantons in 1846-1848, the confederal and later federal trend, the weakening of the cantons, and, once again, cantons' endeavors for more powers in federal decision-making.

Enhanced cooperation contributes to cooperative federalism in Switzerland, forming a vast realm of formal and informal relations and institutions. Democratic forms of cooperation among cantons and with the participation of the Confederation bring decision-making closer to the citizens; serving the everyday needs of the citizens, which are better seen and obvious from the cantonal perspective versus the federal level. The democratic character of Swiss federalism is rooted in the recognition of the persisting ambitions of some cantons to feel independent and sovereign, on the one hand, and having a wide autonomy of communes and allocation of their diversities, on the other hand. This three-tier system - federal center, cantons, communes - made Switzerland one of the most effective federations in the world.

The USA. The example of the USA demonstrates the oldest practice of what is now called the flexibility principle. It is authorized by the US Constitution, namely in the Compact Clause, which is Article I, Section 10, Clause 3: "No State shall, without the Consent of Congress . . . enter into any Agreement or Compact with another State, or with a foreign power," (The Constitution of the United States, 1787). By virtue of exception, the US Constitution authorizes the agreements or compacts among states of the United States, the only condition being that the latter should be given congressional consent. Hereby, the US Constitution authorizes the horizontal form of enhanced cooperation.

The US Supreme Court, however, has ruled that not all interstate agreements must obtain the approval of Congress. In Virginia v. Tennessee (U.S. Supreme Court, 1893) it held that Congress must approve only two types of compact: those that alter the balance of political power between the states and federal government; and those that intrude on power reserved for Congress. If Congress grants consent, a compact becomes federal law (Cuyler v. Adams, 1981).

The system of interstate cooperation in the USA includes compacts concluded among the US states and the agencies formed by the states in the purposes of interstate cooperation and implementation of the above compacts. "An interstate compact is a formal binding contract, authorized by or enacted as legislation, 
between two or more states in their capacity as states" (Litwak, McCabe, Buenger \& Masters, 2016, xix).

In the USA, the principle of flexibility has been in use in this form or the other for about 250 years. Well before the United States was established under the Articles of Confederation and Perpetual Union (Articles of Confederation), colonial authorities had experience of using mechanisms and processes similar to compacts to resolve their disputes. Rooted in the American colonial era, the compacts are the oldest mechanism available to promote formal interstate cooperation (Litwak, McCabe, Buenger, Masters, 2016, p. 4). The very first compacts in American history were drawn up over state boundary disputes as in the cases of Rhode Island v. Massachusetts (U.S. Supreme Court, 1838) and Virginia v. Tennessee. It was the $20^{\text {th }}$ century when compact practices developed rapidly and began to cover the multiple spheres of everyday life, including regional and national policy problems. The areas where states utilized this mechanism included environmental protection, regional transportation, water and oil management, nuclear waste disposal, land use planning, pollution control, economic development, crime control, insurance and licensing. Examples of these compacts are the Interstate agreement on Detainers, the Missouri-Nebraska Boundary Compact, the Central Arizona Project, the Interstate Compact on the Placement of Children, the Tahoe Regional Planning Compact, etc. In the $21^{\text {st }}$ century the states concluded the Great LakesSt. Lawrence River Basin Water Resources Compact, the Surplus Lines Insurance Multi-State Compliance Compact (SLIMPACT), the Interstate Compact on Educational Opportunity for Military Children, the Interstate Compact for Juveniles, the Interstate Compact for Adult Offender Supervision, etc. Physical Therapy and Telepsychology Licensing Compacts, the Medical Licensing Compact, and the State Authorization Reciprocity Agreement are under development.

Interstate compacts have served an important - albeit largely unnoticed role in shaping relationships between the states and, at times, between the states and the federal government. However, the practice of enhanced cooperation in the USA has developed in the direction of the growing participation of the federal government in inter-state compacts. For example, the federal government is party to the Interstate agreement on Detainers from 1971 (Fried, 1978, p. 1). When it joined, it did so as a "state" for purposes of the agreement, and is in an equal position with the states of the US (Interstate Agreement on Detainers Act, 1970). The symbiosis of horizontal and vertical forms of enhanced cooperation and the equal status of the federal center and the states in the latter is the peculiarity of American system of enhanced cooperation.

The formation of enhanced groups of states introduces asymmetry to the US federal system. Some American scientists view these interstate arrangements as incompatible with federalism. Interstate compacts violate the pure principles of federalism creating sub-federal, supra-state administrative agencies, and a third tier of governing authority (Broun, Buenger, McCabe \& Masters, 2006, p. 11).

In our opinion, the possibility for states to form enhanced groups in order to foster cooperation in particular areas brings the democratic element into the US federal system. The mere fact that the constituent units are granted the right to cooperate and to conclude agreements is a reflection of the democratic attitude 
of the federal center towards the units. This not only grants the constituent units additional rights but also increases their accountability. The practicalities of governing a large, multifaceted, federally designed nation frequently blurs the lines of what is distinctly national in scope and what is local. Some 30 of the largest metropolitan areas in the United States extend across state lines affecting 25 percent of the population of the United States. This is precisely where interstate compacts provide an effective solution in addressing supra-state problems (Ibid., p. 26).

Moreover, federal authorities are often reluctant to meet the regional and local needs. The compacts are a way to overcome federal insensitivity. At the same time, the compacts can effectively preempt federal interference into matters that are traditionally within the purview of the states but that have regional or national implications (Ibid., p. 27).

Over the years, interstate cooperation in the USA has proven to be an important and necessary feature of American democracy.

Canada. The analysis of Canadian intergovernmental agreements reveals that a strong tendency for active and long-time federal-provincial, and later, federal-provincial/territorial cooperation has existed. Although the Constitution of Canada of 1867 does not mention it, the provision authorizing the federal-provincial/territorial cooperation can be found in the Meech Lake Accord of 1987. It is stated in the Preamble that first ministers would provide new arrangements to foster greater harmony and cooperation between the Government of Canada and the governments of the provinces and would require that annual constitutional conferences composed of first ministers be convened (Meech Lake Accord, 1987).

The increasing role of governments has required them to enter into agreements in relation to many activities, whether they are of federal, provincial or shared jurisdiction. The vertical dimension of enhanced cooperation is rather well developed in Canada. Since 1922 more than 2900 federal-provincial agreements were signed in various sectors, such as education, health and the environment. One of the first federal-provincial agreements - on the issue of immigration, a constitutional power shared between the Parliament of Canada and the provincial legislatures - was concluded in 1868. Federal-provincial/territorial agreements have since multiplied. The examples are the Canada Job Fund agreements, the Gas Tax Fund Agreements, the Infrastructure Bilateral Agreements, the Infrastructure Framework Agreements, and the Bilateral Health Agreements. In 2009-2013 the Reciprocal Taxation Agreements with provinces and territories were signed between the Canadian government and 8 provinces and 3 territories. The exceptions were Alberta and New Brunswick.

The Government of Canada has entered into an Environmental Occurrences Notification Agreement with the government of each of the following provinces and territories: Ontario, Manitoba, British Columbia, Saskatchewan, Alberta, Yukon and the Northwest Territories. The purpose of these Notification Agreements is to establish a streamlined notification system and reduce duplication of effort for persons required to notify federal and provincial/territorial governments of an environmental emergency or environmental occurrence, such as an oil or chemical release. Under these Notification Agreements, 24-hour authorities operating for 
the provinces and territories receive emergency or occurrence notifications and transfer this information to the federal Department of the Environment, which is essential for the timely and effective oversight of the response, as may be warranted (Government of Canada, 2017).

The most recent example is the Canadian Free Trade Agreement of 2017 (Canadian Free Trade Agreement, 2017).

The bilateral "province-to-province" and multilateral agreements of which the Canadian government is not party to, form another horizontal layer of legislation. The examples are the Reciprocal Agreement between the Province of Ontario and Québec concerning Drivers' Licences and Traffic Offences of 1988 and a large group of Trade Enhancement Arrangements with the participation of two to five provinces and (or) territories such as the New West Partnership Trade Agreement, the Trade and Cooperation Agreement between Québec and Ontario, and the Interim Agreement on Internal Trade in Agriculture and Food Goods, etc.

The Constitution of Canada makes a clear distinction between provinces and territories. The provinces exercise constitutional powers in their own right; the territories exercise delegated powers under the authority of the Parliament of Canada. This a priori asymmetry of Canadian federalism is based on the different status of provinces and territories. However, over the past 40 years, major changes have occurred in the governance of the territories. Federal statutes have established a legislative assembly and executive council for each territory and province-like powers are increasingly being transferred or "devolved" to territorial governments by the Government of Canada. This process, known as "devolution", provides greater local decision-making and accountability (Government of Canada, 2017).

The a priori asymmetry in Canada is combined with treaty-based asymmetry shaped by the various federal-provincial/territorial arrangements. Provinces and territories form different groups solving a wide variety of problems, including agreements, constitutional and regular conferences, joint agencies, etc. The participation of the Canadian government in a large number of agreements on an equal footing with constituent units (as in the Free Trade Agreement of 2017) shows the respect for the latter from the part of the federal center and the willingness of the federal government to support the two-level sovereignty in Canada.

The Russian Federation. Enhanced cooperation in the Russian Federation has been developed since 1992 in its horizontal and vertical dimensions. The federative system in Russia demonstrates different forms of cooperation among constituent units of federation and constituent units and the federal center.

The well-known Federative Treaty was signed on March 31, 1992 by all constituent units of the Russian Federation with the exception of Tatarstan and Chechnya. It was the first document to form the basis for asymmetry in the Russian federal realm: it consists of three treaties each regulating the relationships of the federal center and the different types of constituent units. The scope of competencies of the latter is different.

The constituent units of the Russian Federation implementing the relevant provision of the federal Constitution (Constitution of the Russian Federation, 1993), initiated bilateral treaties with the federal center. It was in February 1994 
when the first treaty was concluded between the Russian Federation and the Republic of Tatarstan. It regulated delimitation of jurisdictional subjects and mutual delegation of authorities between the bodies of state power of the Russian Federation and the bodies of state power of the Republic of Tatarstan. The treaty tried to fill the gap that occurred in the system of delimitation of jurisdictional subjects between the federal center and constituent units. As a matter of fact, the exclusive competencies of the federal center and the joint competencies of the federal center and the constituent units are regulated in detail in the federal Constitution, while the exclusive competencies of the constituent units are being formed residually, i.e. after what is left beyond the competencies of the federal center and joint competencies.

The constituent units of the Russian Federation had followed the first "vertical" treaty and 42 treaties were concluded between the Russian federal center and constituent units.

The treaty administrative practice, however, was active only until 1998; since that year no more treaties have been concluded. At the turn of the century, the tendency in the development of the Russian Federation has changed gradually. The issue of delimitation of jurisdictional subjects between the bodies of state power of the Russian Federation and the bodies of state power of constituent units was regulated by the federal law (Federal law, 1999). Federal laws have supremacy over bilateral treaties. In 2001-2002, most of constituent units terminated the treaties with the federal center. The Republic of Tatarstan was the only constituent unit to conclude a new treaty in 2007 for the term of ten years. Now the possibility and necessity for a new treaty is widely discussed.

Enhanced cooperation was vitally important in a multi-ethnic state like the Russian Federation. We support the well-known thesis of the Soviet era that federalism was a form of solving the nationality issue. We assume that asymmetry in Russia is a priori asymmetry and begins from the very structure of the federal setting, i.e. the existence of six different types of constituent units. According to the Russian Constitution, their status is different: being "a state" for the republics, and an ordinary constituent unit for a krai, oblast, etc. This asymmetry can be called functional, or formal, having its basis in the federal Constitution. Enhanced cooperation in its vertical form gives rise to another type of asymmetry - the treaty-based asymmetry; it presupposes the differences in status of the units of one level. For example, all of the republics had treaties with the federal center, but the scope of the exclusive authority they gained out of these was different. Moreover, three treaties - with Tatarstan, Kabardino-Balkaria and Bashkortostan - regulated not only the delimitation of jurisdictional subjects between the federal and regional levels, but also the mutual delegation of authorities, which means equal relationships between the two levels of federation in the issue of delegation of authorities.

As the vertical treaties were no longer prolonged, the constitutional mechanism of delimitation of authorities was left to be a single mode of delimitation of authorities in the Russian federal system. Only the treaty between the federal center and the Republic of Tatarstan had its continuation; it was adopted by federal law in 2007 (Federal law, 2007). 
The vertical enhanced cooperation in the Russian Federation in the 90s introduced treaty-based asymmetry into the federal system. The constituent units were each granted its own list of exclusive competencies. This multi-asymmetric federal system ensured the democratic rights in a broader sense and in a specific way vis-à-vis the constituent units. The multiethnicity of Russia and the rights of national groups were taken into account. Republics and the other constituent units were granted the possibility to pursue their own manner of development with due attention to national, historic, cultural, linguistic and confessional peculiarities. They have since formed a modern structure of state power and legislation, implemented individual models of economic and social reforms and formed institutes of civil society. The well-known example is "the soft entry into the market [economy - added by G. Sh.]" in Tatarstan.

The Russian Federation of 1992-2002 was a multi-asymmetric constitutional-treaty federation. As the vertical dimension of enhanced cooperation does not practically develop nowadays, the form of federation has changed into asymmetric constitutional. However, the possibility of returning to the treaty practices is not prohibited by law and is used by some constituent units.

\section{Results}

1. An examination of case studies of Switzerland, Canada, the USA and the Russian Federation reveals that enhanced cooperation in modern federations has horizontal and vertical dimensions. The horizontal cooperation is represented by agreements among constituent units of a federation, the vertical cooperation is represented by agreements between a federal center and constituent unit(s). The horizontal dimension of enhanced cooperation is rather strong in all federations, the vertical dimension is well developed in Canada and Switzerland, less developed in the USA and poorly represented in modern Russia. In terms of authorizing enhanced cooperation by law, federations of the Romano-German family - Switzerland and Russia - regulate it in federal constitutions; federations of Anglo-Saxon family - the USA and Canada - either do not regulate it through the basic law or do it by virtue of exception, as in the USA. Enhanced cooperation is being developed ad hoc due to recognition by courts.

2. The implementation of the principle of flexibility introduces the treaty element into the structure of a federation, in particular when the treaties are concluded on the initiative of a federal center or with its participation. The USA and Switzerland are classic treaty federations, while Russia passed the period of a de jure constitutional-treaty federation in 1992-2002 and is now a de facto constitutional federation.

3. Asymmetric federations based on enhanced cooperation belong to the cooperative type of federations. They provide formal and informal procedures and institutions for the collaboration of two levels of authorities, very often with the participation of the municipal level. Cooperative federalism is a unique form of checks and balances that allows the constituent units not to be concerned about any possible seizure of their powers by a federal center and to maintain strong confidence in negotiating cooperation. 


\section{Conclusions}

Enhanced cooperation inevitably leads to asymmetry within the federal system. Very often, it is the second level of asymmetry following the a priori form of asymmetry, being understood as a constitutionally regulated unequal status of constituent units such as provinces and territories in Canada or six different types of units in the Russian Federation. This second level of asymmetry can be called treaty-based asymmetry because it originates from the treaties concluded among constituent units and (or) a federal center. The possible results of treatybased asymmetry are twofold: (1) the formation of enhanced groups of constituent units that solve the issues of mutual concern and (2) the establishment of different status for the units of one level with the backing of a federal center.

Asymmetric federation as a pluralistic form ensures democratic rights, the minorities' rights, representation and participation. Asymmetric federation is a mutual acknowledgement of the status of a federal center and constituent units. In these relationships, the respect for the rights of the units from the part of a federal center is a key element. Asymmetric federations are the response to the challenge of the units for the federal government. The democratic rights in linguistic, cultural, religious and economic spheres do not often require the same level of recognition. One national or linguistic group will be content with the cultural autonomy; the other will be satisfied with the status of the constituent unit of a federation. The asymmetric composition of a federation allows for responding to these different ambitions in different forms. The possibilities vary from territorial and cultural autonomy to the constituent units and associated states.

There is no doubt that asymmetric federation is a more complex and difficult to manage polity in comparison with symmetric federation. However, there are signs of asymmetry even in classic symmetric federations despite it not being authorized by law. Federations as dynamic, self-developing societies accommodating diverse groups and interests react to the challenges of these diversities and keep them united in order to achieve mutual progress.

\section{REFERENCES}

1. Broun, C., Buenger, M., McCabe, M. \& Masters, R. (2006). The Evolving Use and Changing Role of Interstate Compacts: A Practitioner's Guide. American Bar Association (4 December).

2. Conlan, T. (2002). Flexibility in the American Context. Flexibility in Constitutions. Europa Law Publishing, pp. 43-46. 
3. Diamond, M. (1961). The Federalist's View of Federalism. In: Benson, George (ed.) Essays in Federalism. Institute for Studies in Federalism, Claremont, p. 22.

4. Elazar, D. (1987). Exploring Federalism. University of Alabama Press, 1987, pp. 107-109.

5. Elazar, D. (1995). Federalism: An Overview. Pretoria: Daniel J. HSRC Publishers, p. 13.

6. Farukshin, M. (2003). Sravnitelnyi federalism: Uchebnik po spetskursu [Comparative federalism: the Textbook for the course]. Kazan: Izdatelstvo Kazanskogo universiteta.

7. Fleiner, T., Misic, A. \& Topperwien, N. (2005). Swiss Constitutional Law. Kluwer Law International.

8. Fried, B. (1978). The Interstate Agreement on Detainers and the Federal Government. Hofstra Law Review, vol. 6, no 3, part I, Spring.

9. Goudappel, F. (2002). Switzerland: From Confederation to Federation through Flexibility. Flexibility in Constitutions. Europa Law Publishing, 2002, pp. 27-30.

10. Litwak, J., McCabe, M., Buenger, M. \& Masters, R. (2016). The Evolving Law and Use of Interstate Compacts. $2^{\text {nd }}$ Edition. ABA Book Publishing.

11. López - Basaguren, A. \& Escajedo San Epifanio, L. (2013). The Ways of Federalism in Western Countries and the Horizons of Territorial Autonomy in Spain: Vol. 2. Springer Science \& Business Media.

12. Van Wissen, G. (2002). Flexibility in German Constitutional Law. Flexibility in Constitutions. Europa Law Publishing, 2002, pp. 19-24.

\section{DOCUMENTS AND LAWS}

1. Canadian Free Trade Agreement (2017). Available: http://www.ait-aci.ca/wp-content/ uploads/2017/04/CFTA-Consolidated-Text-Final-English.pdf (accessed: 30 May, 2017).

2. Constitution of the Russian Federation, 1993. Article 11(3). Available: http://www. constitution.ru/en/10003000-02.htm (accessed: 30 May, 2017).

3. Constitution of the United States. Available: http://constitutionus.com/ (accessed: 30 May, 2017).

4. Constitution of Switzerland. Available: https://www.admin.ch/opc/en/classifiedcompilation/19995395/201601010000/101.pdf (accessed: 31 May, 2017). 
5. Cooperation Agreement between the Confederation and Cantons (2015). Available: https://www.admin.ch/opc/de/classified-compilation/20143159/index.html (accessed: 30 May, 2017).

6. Cuyler v. Adams (1981). 449 U.S. 433. Certiorari to the United States Court of Appeals for the Third Circuit. U.S. Supreme Court. Available at: https://supreme.justia. com/cases/federal/us/449/433/case.html (accessed: 30 May, 2017).

7. Federal law (1999). Federal'nyi zakon ot 24.06.1999 N 119-FZ "O printsipakh i poryadke razgranicheniya predmetov vedeniya i polnomochiy mezhdu organami gosudarstvennoy vlasti Rossiyskoy Federatsii i organami gosudarstvennoy vlasti sub" ektov Rossiyskoy Federatsii [Federal law. 24.06.1999 N 119-FZ "About the principles and order of distribution of subject matters and authorities between the state authorities bodies of the Russian Federation and the state authorities bodies of the subjects of the Russian Federation]. 317 6); expired.

8. Federal law (2007). Ob utverzhdenii Dogovora o razgranicheniya predmetov vedeniya i polnomochii mezhdu organami gosudarstvennoi vlasti Rossiiskoi Federatsii i organami gosudarstvennoi vlasti Respubliki Tatarstan [The agreement on the delimitation of the subjects of jurisdiction and authority between the bodies of state authority of the Russian Federation and bodies of state power of the Republic of Tatarstan]. Moscow, June. Available at: http://tatarstan.ru/documents/polnomochia.htm (accessed: 29 May, 2017).

9. Government of Canada, 2017. Available at: http://www.cic.gc.ca/english/department/laws-policy/agreements/index.asp (accessed: 30 May, 2017).

10. Interstate Agreement on Detainers Act. Pub. L. 91-538, \$1, Dec. 9, 1970, 84 Stat. 1397. Available at: http://uscode.house.gov/view.xhtml?path=/prelim@title18/title18a/ node5\&edition=prelim (accessed: 30 May, 2017).

11. Interstate Agreement on Detainers Act. Pub. L. 91-538, \$1, Dec. 9, 1970, 84 Stat. 1397. Available at: http://uscode.house.gov/view.xhtml?path=/prelim@title18/title18a/ node5\&edition=prelim (accessed: 30 May, 2017).

12. Meech Lake Accord, 1987. Available at: http://www.thecanadianencyclopedia.ca/en/ article/meech-lake-accord-document/ (accessed: 29 May, 2017).

13. Reciprocal Agreement between the Province of Ontario and Québec concerning Drivers' Licences and Traffic Offences of 1988. Available at: http://legisquebec.gouv. qc.ca/en/ShowDoc/cr/C-24.2,\%20r.\%2022/ (accessed: 30 May, 2017).

14. Rhode Island v. Massachusetts (U.S. Supreme Court, 1838). Available at: https://supreme. justia.com/cases/federal/us/37/657/case.html (accessed: 30 May, 2017).

15. Virginia v. Tennessee (U.S. Supreme Court, 1893). Available at: https://supreme.justia. com/cases/federal/us/148/503/case.html (accessed: 30 May, 2017). 